\title{
Fremtiden er lys!
}

Hvilke forskningsteknikker vil være viktige det neste tiåret? To nye gjennombrudd muliggjør forskning på levende dyr, og begge benytter seg av et nokså grunnleggende forskningsverktøy - lys.

Moderne medisin har flere viktige verktøy til bildeundersøkelser av levende pasienter, blant annet magnetisk resonanstomografi (MR), computertomografi (CT) og positronemisjonstomografi (PET). Dessverre mangler alle disse teknikkene oppløsning til å studere enkeltceller og subcellulære hendelser (1).

Lys- og elektronmikroskopering har oppnådd høyere oppløselighet ved å bruke kortere bølgelengde, men det innebærer at vevet tilføres høyere energi og lettere blir skadet. Mange elektron- og lysmikroskop kan derfor ikke brukes på levende individer.

\section{Lys og gener}

Mikroskoper trenger kontrast for «å se». En av de mest populære metodene for å oppnå kontrast til lysmikroskopi er å tilføre vevet fluorokromer - molekyler som absorberer lysenergi og sender tilbake lys med en litt lengre bølgelengde enn det som kom inn (fluorescens). Oppdagelsen av at man kan klippe ut gener som koder for fluorescerende proteiner hos manet, og lime dem inn $i$ arvematerialet til for eksempel mus, ga grunnlaget for forskningsfeltet optogenetikk. Det førte frem til Nobelprisen i kjemi i 2008 (2).

Man har nylig utviklet metoder for ikke bare å se på subcellulære prosesser, men også påvirke dem direkte med lys. En av de mest komplekse proteinfamiliene i naturen er den lysfølsomme opsinfamilien. Opsiner finnes i bakterier, Archaea og eukaryote organismer, ofte som ionekanaler som åpner eller lukker seg når de blir stimulert av lys. Hos mennesker og andre pattedyr finnes det bare opsinproteiner i netthinnen (rodopsin i staver, 2-3 fotopsiner i tapper og mela- nopsin i ganglieceller involvert i regulering av døgnrytme) og en etterlevning etter evolusjonen i corpus pineale (melanopsin) (3). Opsin fra alger er via lentivirus blitt satt inn i nerveceller hos mus, og man kan på den

\section{«Kombinasjonen opto- genetikk og tofoton- mikroskopi har vist seg å åpne nye muligheter»}

måten via lys depolarisere cellen (4). Dette representerer et gjennombrudd fordi man kan stimulere eller hemme enkeltceller i levende dyr direkte og se hva som skjer.

Etter hvert har man også utviklet metoder for å lysstimulere fritt bevegende mus med fiberoptiske kabler eller små subkutant implanterbare lyskilder med trådløs sender, slik at musene kan fjernstyres $(5,6)$. På denne måten kan optogenetikk også ha viktige terapeutiske applikasjoner, ved for eksempel å aktivere immunceller eller stimulere tilheling i et lite område. Man har også laget lyssensitive G-protein-koblede reseptorer og kalsiumindikatorproteiner som muliggjør manipulasjon og måling av subcellulære hendelser $\mathrm{i}$ «sanntid» med millisekunders nøyaktighet (7).

\section{Kvantefysiske knep}

De fleste relevante lysfølsomme eller fluorescerende proteinene krever lys med nokså høy energi for å bli stimulert (blått-grønt).
Det medfører varmeskade i vevet og begrenser hvor dypt vi kan «se» $(<50 \mu \mathrm{m}$ eller ett par cellelag).

I 1990 ble det mulig å utvikle lasere som var kraftige nok til å oppnå den kritiske «fotonkonsentrasjon» for å stimulere et molekyl med to eller flere lyspartikler samtidig (8). Laserne pulserer med ultrakorte (femtosekund) pakker med høy tetthet av lyspartikler, og kalles derfor ofte femtosekundlasere. Når to eller flere fotoner treffer et fluorokrom på likt, slår energien seg sammen, og det medfører at man kan bruke lyspartikler som enkeltvis har lav energi (lang bølgelengde, rød og infrarød farge). Dermed reduseres vevsskaden, samtidig som dybden på hva vi kan se, øker eksponensielt (vanligvis 500 til $1000 \mu \mathrm{m}$, siden lysspredning er eksponentielt korrelert med mindre bølgelengde). Teknikken kalles tofoton- eller multifotonmikroskopi, og har i likhet med konvensjonell lysmikroskopi høy oppløselighet i tid (under $100 \mathrm{~ms}$ ) og rom (under $1 \mu \mathrm{m}$ ). Det muliggjør blant annet studier av enkeltsynapser i hjernen.

Andre gjennombrudd innen optiske bildeteknikker, slik som akustooptiske modulatorer (AOM) er også i senere tid blitt kombinert med tofotonmikroskopi. Dette har økt hastigheten på bildeopptaket fra tre per sekund til tusener og gjør det mulig å avbilde elektriske enkeltimpulser (9). De såkalte femtosekundlaserne som brukes til slik forskning, kan også brukes til å skjære med mikrometers presisjon dypt i vev, slik som hornhinne eller linse, uten å skade strukturer på vei inn. Denne teknikken står for noen av de siste gjennombruddene innen operativ korreksjon av brytningsfeil og fjerning av grå stær (såkalt femto-LASIK, SMILE og FLACS) (10).

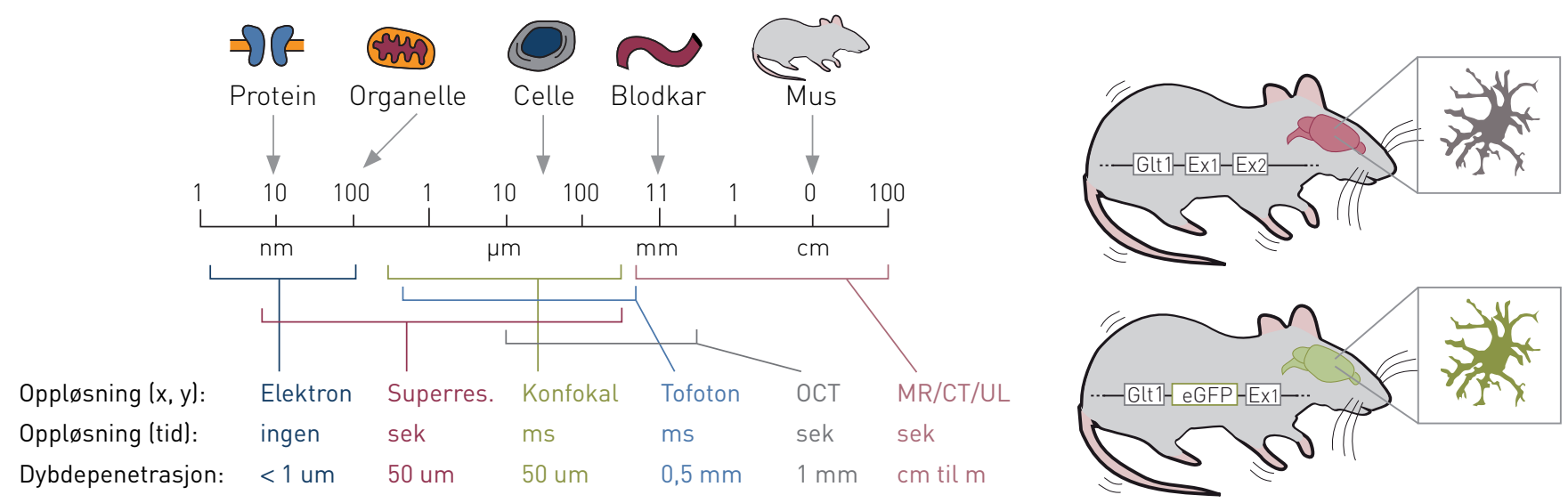

Figur 1 Bildeoppløsning og metoder for å oppnå bildekontrast ved hjelp av optogenetikk. Venstre panel: Bildeoppløsning i tid, rom (x, y) og dybde (dybdepenetrasjon) for noen av de vanligste teknikkene. Forkortelser: elektronmikroskopi (Elektron), superresolusjonsmikroskopi med lys (Supperres.), konfokalmikroskopi (Konfokal), tofotonmikroskopi (Tofoton), «optical coherence tomography» (OCT), ultralyd (UL). Høyre panel: Her er genet for «enhanced green fluorescent protein» (eGFP) «limt inn» etter promoteren for genet Glt1, slik at støttecellene i hjernen fluorescerer grønt 
a

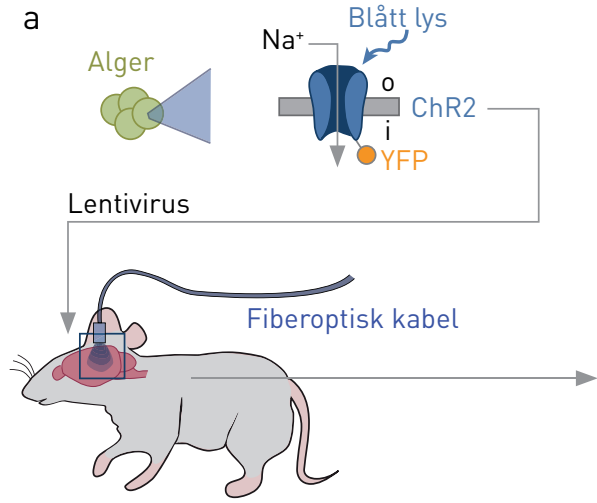

Mus som beveger seg fritt b

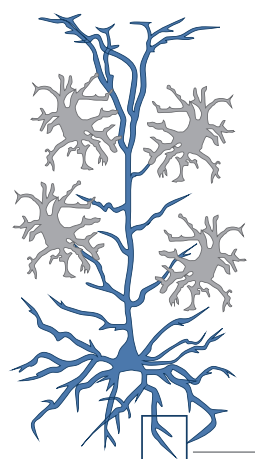

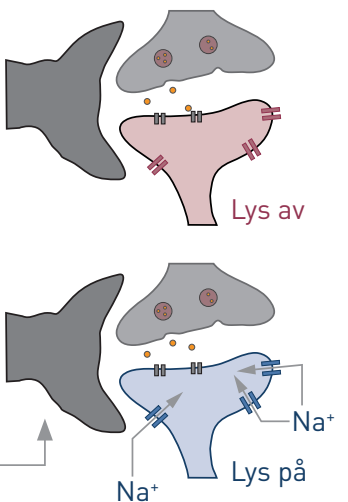

d

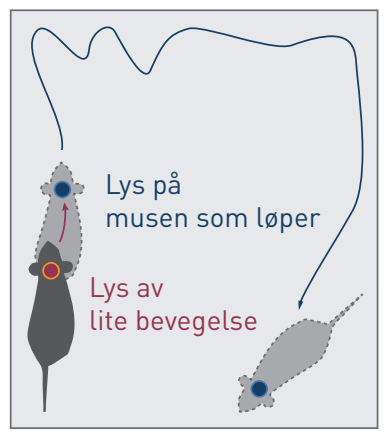

Figur 2 Fjernstyring av mus med optogenetikk. Genet for Channelrhodopsin 2 (ChR2) «klippes ut» av alger, og «limes inn» i hjerneceller hos mus ved hjelp av en lentivirusvektor. Musene kan da fjernstyres ved hjelp av en fiberoptisk kabel som appliserer blått lys til en spesifikk hjerneregion (premotor cortex her). Når lyset slås på, vil $\mathrm{Na}^{+}$strømme inn i nervecellene, og det gjør at musen løper rundt buret. Forkortelser: «yellow fluorescent protein» (YFP, her brukt som en reporter)

Nye optiske knep har gitt flere uante muligheter. De har muliggjort visualisering av fyrende nerveceller i hjernebarken på mus som beveger seg i en virtuell labyrint (11), og har belyst spørsmål om hvordan minner lagres $(12,13)$ og hvordan epileptiske kramper oppstår $(14,15)$.

\section{Nye muligheter}

Drøyt 200 år etter at den franske fysikeren Augustin-Jean Fresnel (1788-1827) beskrev lys som en bølge, byr naturen fortsatt på nye optiske knep og muligheter. Kombinasjonen optogenetikk og tofotonmikroskopi har vist seg å åpne nye muligheter for forskning, diagnostikk og potensielt behandling. Fremtiden kan med rette sies å være lys.

\section{Alexander S. Thrane}

alexander.thrane@gmail.com

Per S. Thrane

Alexander S. Thrane (f. 1984) er konstituert overlege ved Øyeavdelingen, Haukeland universitetssykehus. Han har en bistilling som forsker hos oftalmogenetisk gruppe ved Haukeland universitetssykehus, og ved Institutt for medisinske basalfag, Universitetet i Oslo.

Forfatter har fylt ut ICMJE-skjemaet og oppgir ingen interessekonflikter.
Per S. Thrane (f. 1955) er lege og tannlege, spesialist i periodonti med spesialkompetanse i patologi og immunologi. Han er professor ved Avdeling for periodonti, Institutt for klinisk odontologi, Det odontologiske fakultet, Universitetet i Oslo.

Forfatter har fylt ut ICMJE-skjemaet og oppgir ingen interessekonflikter.

\section{Litteratur}

1. Misgeld T, Kerschensteiner M. In vivo imaging of the diseased nervous system. Nat Rev Neurosci 2006; 7: 449-63.

2. Chalfie M, Tu Y, Euskirchen $G$ et al. Green fluorescent protein as a marker for gene expression. Science 1994; 263: 802-5.

3. Terakita A. The opsins. Genome Biol 2005; 6: 213.

4. Boyden ES, Zhang F, Bamberg E et al. Millisecondtimescale, genetically targeted optical control of neural activity. Nat Neurosci 2005; 8: 1263-8.

5. Montgomery KL, Yeh AJ, Ho JS et al. Wirelessly powered, fully internal optogenetics for brain, spinal and peripheral circuits in mice. Nat Methods 2015; 12: 969-74.

6. Aravanis AM, Wang LP, Zhang F et al. An optical neural interface: in vivo control of rodent motor cortex with integrated fiberoptic and optogenetic technology. J Neural Eng 2007: 4: S143-56.

7. Mao T, O'Connor DH, Scheuss $V$ et al. Characterization and subcellular targeting of GCaMP-type genetically-encoded calcium indicators. PLoS One 2008: 3: e1796.

8. Denk W, Strickler JH, Webb WW. Two-photon laser scanning fluorescence microscopy. Science 1990; 248: $73-6$.

9. Svoboda K, Yasuda R. Principles of two-photon excitation microscopy and its applications to neuroscience. Neuron 2006; 50: 823-39.

10. Soong HK, Malta JB. Femtosecond lasers in ophthalmology. Am J Ophthalmol 2009; 147: 189-197.e2.

11. Harvey CD, Collman F, Dombeck DA et al. Intracellular dynamics of hippocampal place cells during virtual navigation. Nature 2009; 461: 941-6.

12. Gu L, Kleiber $S$, Schmid L et al. Long-term in vivo imaging of dendritic spines in the hippocampus reveals structural plasticity. J Neurosci 2014; 34: 13948-53.

13. Low RJ, Gu Y, Tank DW. Cellular resolution optical access to brain regions in fissures: imaging medial prefrontal cortex and grid cells in entorhinal cortex. Proc Natl Acad Sci U S A 2014; 111: 18739-44.

14. Rangroo Thrane V, Thrane AS, Wang F et al. Ammonia triggers neuronal disinhibition and seizures by impairing astrocyte potassium buffering Nat Med 2013; 19: 1643-8

15. Muldoon SF, Villette V, Tressard T et al. GABAergic inhibition shapes interictal dynamics in awake epileptic mice. Brain 2015; 138: 2875-90.

Mottatt 19.1. 2016, første revisjon innsendt 7.2. 2016, godkjent 11.2. 2016. Redaktør: Ketil Slagstad.

Publisert først på nett. 